\section{ДОСЛІДЖЕННЯ ОСОБЛИВОСТЕЙ РОЗВИТКУ КРУЇзНОї ІНДУСТРІї}

\author{
MAKAPEHKO M. B., \\ доктор економічних наук, \\ професор, \\ HOCOBCbKA O. Б., \\ кандидат технічних наук, доцент \\ Азовський морський інститут \\ національного університету \\ «Одеська морська академія», \\ ПОТАПОВА Н. М., \\ кандидат економічних наук, \\ доцент, ДВНЗ «Приазовський \\ державний технічний \\ університет»
}

\section{RESEARCH OF FEATURES OF CRUISE INDUSTRY DEVELOPMENT}

\author{
MAKARENKO M., \\ Doctor of Science in Economics, \\ Professor, \\ NOSOVSKA O. \\ PhD in Technical Sciences, \\ Associate Professor, Azov \\ Maritime Institute National \\ University "Odessa Maritime \\ Academy", \\ POTAPOVÁ N., \\ $\mathrm{PhD}$ in Economics, Associate \\ Professor, State Higher \\ Educational Institution "State \\ Technical University"
}

У статті досліджено напрямки розвитку круїзного туризму. Розглянуто сегменти ринку туристичних послуг за регіонами світу. Проаналізовано класифікацію круїзних напрямків, встановлені провідні компанії галузі та визначено специфіку послуг та споживачів їх продукції. Визначені тенденції розвитку круїзних лайнерів та майбутнього попиту на них.

Ключові слова: круїзний туризм, круїзні лайнери, ринок туристичних послуг, напрямки круїзних подорожей, круїзні лінії.

В статье исследованы направления развития круизного туризма. Рассмотрены сегменты рынка туристических услуг по регионам мира. Проанализированы классификации круизных направлений, установлены ведущие компании отрасли и определена специфика их услуг и потребителей продукции. Определены тенденции развития круизных лайнеров и будущего спроса на них.

Ключевые слова: круизный туризм, круизные лайнеры, рынок туристических услуг, направления круизных путешествий, круизные линии.

The article explores the directions of development of cruise tourism. Segments of the market of tourist services by regions of the world are considered. The classifications of cruise directions have been analyzed, the leading companies in the industry have been identified and the specifics of their services and consumers of products have been determined. Trends in the development of cruise ships and future demand for them have been identified.

Key words: cruise tourism, cruise liners, tourist services market, cruise travel directions, cruise lines.

Постановка проблеми. Круїз визначається як «здійснення морської поїздки на лайнері для відпочинку, зазвичай заїжджаючи в декілька портів» [2]. Воно характеризується тим, що судно подібне до мобільного курорту, який перевозить пасажирів (гостей) з місця на місце. Сьогодні судна розглядаються не як транспортний засіб, а як готелі на воді. За даними Всесвітньої туристичної організації, витрати на проживання та відповідні курортні послуги складають 73\% для 
судна, а решта присвячена його експлуатації. Ці плавучі курорти імітують наземні аналоги 3 ресторанами, барами, спортивними закладами, торговими центрами, розважальними закладами, центрами зв'язку тощо. Каюти стають більшими та розкішними. Круїзні компанії все частіше просувають та позиціонують свої торгові марки, щоб дати змогу клієнтам ідентифікувати свої послуги в міру зростання конкуренції. Крім того, це дозволяє клієнтам робити менше порівнянь цін і полегшувати прийняття рішень. Наприклад, Carnival Cruises Lines пов'язує характеристики «розважальних лайнерів» 3 їх торговою маркою, тоді як Oueen Elizabeth 2 пропонує більш ексклюзивний образ та унікальний досвід завдяки своїй рекламній темі «раз у вашому житті, жити». Круїзи Діснея створюють виразну привабливість бренду для дітей. У міру збільшення круїзного ринку потреба в брендінгу стане більше помітною. Розвиток круїзного туризму феноменальний. Відродження круїзів відбулося за останні чотири десятиліття, і сьогодні воно становить невелику, але зростаючу частину у світовій туристичній галузі. Круїзний туризм $є$ нішевою формою або видом туризму. Що стосується його розміру в галузі, то круїзні судна становлять лише 0,6\% готельних місць, що пропонуються у всьому світі [8].

Круїзна індустрія помітно еволюціонувала 3 перших днів існування перших пасажирських суден. Ця еволюція включала екскурсійні подорожі, трансатлантичні подорожі, післявоєнний бум, загибель пасажирських судів та появу сучасних круїзів [3]. Зараз галузь швидко розвивається і $є$ однією з основних галузей зростання туризму на початку нового тисячоліття. Давидоф П. та Давидоф Д. [2] виклали п'ять специфічних особливостей круїзів, які подобаються мандрівникам: пасажири мають можливість відвідати найрізноманітніші місця за короткий проміжок часу без проблем інших видів подорожі; лайнери повністю автономні; круїзні суда мають менеджера круїзів та персонал, єдиною функцією якого $€$ забезпечення приємного проведення часу пасажирами; високоякісні страви подаються в елегантному стилі; усі зазвичай починають і закінчують відпустку в один день.

Аналіз останніх досліджень та публікацій. Питаннями теорії та практики круїзної індустрії займалося багато вчених: Давидоф П. та Давидоф Д. [2], Дикинсон В. та Владимир А. [3], Даулінг Р. [4], Кнего П. [5], Пейдж М. [6], Пислей Т. [7]. Цей напрямок для багатьох країн представляє суттєве джерело надходження доходів й чинник розвитку їх економіки. Отже, розвиток круїзної індустрії потребує особливої уваги й ретельних подальших досліджень.

Метою статті $€$ дослідження напрямків розвитку круїзної індустрії у світі.

Виклад основного матеріалу дослідження. Ключові круїзні регіони - Кариби, Європа та Аляска. У Північній Америці круїзна індустрія зазнає стрімкого зростання за даними американської асоціації круїзних ліній (CLIA) [1], що базується в США. Вона складається з 19 провідних круїзних ліній з більш ніж 150 судами та 16500 туристичних агентств. Заснована у 1975 році, своєю метою має забезпечити форум, де компанії, що займаються маркетингом пасажирських круїзів у США та Канаді, можуть зустрічатися та обговорювати питання, що становлять спільний інтерес, та 
розробляти та узгоджувати політику, спрямовану на просування концепції круїзних подорожей.

Згідно замовленого дослідження Американської асоціації круїзних ліній, галузь приносить дохід у 23 млрд дол. на рік. Таке зростання ілюструється великою кількістю круїзних суден, круїзних ліній та появою круїзних корпорацій. Сьогодні трьома основними 3 них $€$ Carnival, Royal Caribbean International та Star Cruise Corporation. У 2004 році стартував найбільший у світі круїзний лайнер Queen Mary 2, який коштував 800 млн дол. США та перевозив близько 3100 пасажирів та понад 1000 екіпажів. Серйозність, з якою уряди ставляться до цього сектору туристичної галузі, також свідчить про збільшення кількості галузевих організацій, а також про кількість національних та регіональних круїзних стратегій. Завдяки таким темпам зростання, а частково і як наслідок цього, було визначено ряд ключових сегментів, що потребують уваги для задоволення прогнозованого збільшення. Сюди входять стійкість, безпека та розробка продукції. Стійкість є головним питанням круїзних суден, i круїзна індустрія швидко прийняла стійкі принципи у своєму розвитку та діяльності. Згідно з Пейдж М. [6], низка стійких питань, таких як утилізація відходів, відвідування чутливих регіонів вимагають ще більшої уваги. Питання безпеки також вимагають детальної перевірки, оскільки суда стають більшими і відвідують відносно віддалені регіони, такі як Арктика та Антарктика.

Розглянемо деякі сучасні та майбутні проблеми, з якими стикається зростання круїзної галузі. За останні 5 років відкриті нові ринки та послуги, а також з'явилися більші судна. Отже, галузь стикається 3 низкою нових технологій, обладнанням. Круїзна індустрія потребує врахування цих факторів та бути активнішою в ряді інших. Нині спостерігається глобалізація круїзного досвіду в Північній Америці. Пасажири круїзів представлені усіма верствами населення, i $\epsilon$ великий відсоток круїзів, які вперше їх здійснили. Сучасні споживачі круїзів молодші, ніж раніше, і складають у середньому приблизно 45 років, а їхній середній дохід високий (50000 дол.). Попит на круїзи зростає на 50\% кожні 7 років (період 1989-1996 рр. та протягом 19962000 рр.) [8].

Аналіз круїзного ринку показує, що сьогоднішній споживач круїзів - одружений бебі-бумер, який любить подорожувати і часто це робить [1]. Бебі-бумери - це серце круїзного ринку. Близько 34\% таких пасажирів є віком від 3 до 54 років. Три 3 чотирьох $(76 \%)$ пасажирів перебувають у шлюбі, а два 3 п'яти (44\%) - випускники коледжів. Сім'ї $€$ важливим сегментом круїзного ринку. Хоча чоловік/дружина є найімовірнішим супутником круїзу, 16\% пасажирів привозять на круїз дітей до 18 років. Споживачі круїзів - часті мандрівники. Круїзери шукають нових вражень, шукають невідкриті напрямки, і почуваються цілком комфортно в інших культурах. На думку експертів галузі [2, 5], круїз буде підкріплений значним попитом споживачів, новим введенням суден, більшою доступністю американських портів та відновленням інтересу до екзотичних портів. CLIA заявляє, що круїзні судна-члени плавають із понад 100\% заповнюваності, а нове онлайн-опитування вказує, що круїзна діяльність знову зросте у 2022 році. Серед тих, хто відповів на опитування, 85\% заявили, що замовлять ще один круїз у найближчому році [1]. Опитування «Що мені найбільше подобається у круїзі» показало, що близько 66\% оцінили свої останні круїзні канікули як 
відмінні, тоді як обслуговування й харчування також набрало високі оцінки (61\%). Улюбленими курортними напрямками, згідно 3 опитуванням, були Мексика (50\%), Гаваї (25\%) та Аляска (25\%). Відпустка мрій на майбутнє включала круїзи до Карибського басейну (40\%), Флориди (17\%) та Гаваїв (11\%). Улюблені сегменти круїзу включали їжу (29\%), проведення часу з сім'єю (20\%), ідеальну погоду (18\%), відпочинок та релаксацію (16\%) та романтику (12\%). Круїзи по Карибському басейну залишаються найпопулярнішими у світі [1]. Круїзна індустрія класифікує судна за розмірами, кількістю пасажирів та парадними приміщеннями [5]. Вони варіюються від дуже малих або мікро (менше 10,000 тонн і 200 пасажирів) до мега-судів (понад 70000 тонн і більше 2000 пасажирів). Круїзна потужність помітно зросла за останнє десятиліття і не свідчить про зменшення. Судна будь-яких розмірів будуються від малих, розкішних або експедиційних судів до великих мега-лайнерів. Малі судна, як правило, пропонують вищий ступінь обслуговування і представляють більш дорогий сегмент ринку, а отже, їх ціни, як правило, відповідно вище. Окрім збільшення кількості малих судів, спостерігається величезне зростання кількості будованих великих судів, і середній розмір кожного судна зростає. У 1970-х роках вважалося, що 25000 тонн, 800 пасажирських суден $€$ найбільш економічно вигідним і прибутковим [7]. Зараз круїзні суднобудівники вважають, що аргумент про економію масштабу стосується набагато більших суден, оскільки нові судна будуються між 100000 і 150000 тонн місткістю понад 3000 пасажирів. Існує значна економія на масштабі щодо інвестиційних витрат у великі круїзні судна, як це видно з багатьох суден, які замовляються. Більші судна пропонують більший вибір засобів і видів діяльності. Перехід від круїзних судів до плавучих курортів можуть бути завершені лише тоді, коли судна достатньо великі для розміщення тих розважальних закладів, які $€$ в розкішних готелях на березі [4]. Нові круїзні судна, які зараз будуються, розроблені для нових поколінь пасажирів із більш широкими та різноманітними інтересами. Крім того, у них $є$ альтернативні ресторани, різноманітні заходи, розваги, великі кімнати проти маленьких кімнат, місця для куріння сигар, покращення зручностей каюти та комфорт пасажирів. Сучасний круїзний флот курсує від 100 пасажирів до суперлайнерів, побудованих для задоволення понад 3500 пасажирів, що шукають задоволення. Круїз - це вже не сидячий досвід, і круїзні лінії зараз конкурують із наземними комплексами відпочинку. У міру активізації способу життя на березі нові лайнери представляють цілий ряд варіантів, що охоплюють спорт, відпочинок, розваги та культуру. Нові мегалайнери - це гігантські плавучі курорти. Вони мають великі багаторівневі вестибюлі у готельному стилі, скляні ліфти, вражаючі твори мистецтва, вишукані казино, шоу-зали, торгові центри, оздоровчі центри, комп'ютерні та бізнес-центри, дискотеки та оглядові зали. Каюти з невеликими ілюмінаторами замінено каютами 3 великими вікнами та приватними балконами. Зараз судна самі по собі $€$ пунктами призначення, і порти заходу, у багатьох випадках, стають майже другорядними. Зараз круїзні судна оцінюються згідно з низкою різних класифікацій. Найбільш широко використовується рейтинг Berlitz, який оцінює судна відповідно до зручностей, проживання, кухні, обслуговування, розваг та досвіду круїзу [6]. У 2006 році круїзне судно Queen Mary 2 було перевершено 
за розмірами новим - Royal Caribbean International ( $\mathrm{RCl})$. Воно 158000 тонн та довжиною 339 м, 184 футів (56 м) в ширину і 28 футів $(8,5$ м) в осі. Він курсує на 21,6 вузла і вміщає 4370 пасажирів. Зараз він плаває в Карибському басейні на семинічних круїзах. За останні роки однією з визначальних характеристик круїзної галузі стала консолідація основних гравців. Сьогодні в ньому переважають три великі компанії: Carnival Corporation, Royal Caribbean Cruises та Star Cruises Group. Carnival Corporation - найбільша компанія, до якої входять понад 60 судів і 13 торгових марок. Заснована Тедом Арісоном, компанія виросла з одного судна у 1972 році до провідного світового туристичного бренду. Иого материнська компанія Carnival Cruise Lines має флот з 21 судів і $€$ одним 3 наймолодших флотів у світі. Успіх Карнавалу багато в чому був зумовлений введенням його маркетингу «Веселі кораблі», який підняв інтерес потенційних споживачів у 1980-х і 1990-х. У 1996 році він ввів свою «Гарантію відпустки», орієнтовану переважно на пасажирів, які вперше потрапили в літак, в якій зазначалося, що якщо пасажир не задоволений своїм круїзним досвідом, він може висадитися в першому порту заходу і повністю повернути плату за круїз. Він також запровадив ряд інших нововведень у галузі, включаючи Paradise, перший повністю некурящий лайнер. Royal Caribbean Cruises - друга за величиною круїзна група у світі. Він включає круїзи RCI та Celebrity і сильно зосереджений на ринку Північної Америки. Третьою великою корпорацією $€$ Star Cruises Group, заснована малайзійською компанією Genting International Group в 1993 році. Вона швидко зросла на видному рівні і домінувала в Азіатсько-Тихоокеанському круїзному регіоні, а в 2000 році вона взяла на себе норвезькі круїзні лінії та Orient Line. У 2004 році він відкрив NCL America, що базується на Гаваях. Клімат $€$ головним визначальним фактором розгортання судна. Це призводить до переміщення флотів 3 одного пункту призначення в інший.

Основними круїзними територіями $€$ Північна та Центральна Америка (57\% ринку), Європа (24\%) та решта світу (16\%). тоді як 3\% судів простоюють у будь-який конкретний час. Основним круїзним майданчиком $€$ Кариби, базуючись на його близькості до північноамериканського ринку, за яким слідують регіони Середземномор'я, Аляски та Тихого океану. Тоді як раніше типовий круїз тривав протягом кількох тижнів. Короткі круїзи відносно недорогі i пропонують співвідношення ціни та якості, i дають можливість для споживачів, які вперше випробували цей стиль відпочинку. У «обмеженому часом» світі вони також зручніші для сімей та зайнятих керівників. Тематичні круїзи існували з перших днів круїзів, але круїзні лінії почали продавати тематичні круїзи на початку 1980-х як спосіб відрізнити себе, щоб отримати перевагу. Популярні тематичні круїзи включали фокус на танцях, музиці, їжі, вині та здоров'ї та добробуті.

Сьогодні практично всі круїзні лінії пропонують тематичні круїзи. Наприклад, Crystal Cruises пропонують фестиваль вин та продуктів харчування, круїзи здоров'я та фітнесу, круїзи біг-бендів та джазу. Круїзи на острові Гебрід - це замки, сади, піші прогулянки або їзда на велосипеді; Норвезька прибережна подорож має свої переваги Північного сяйва; Fred Olsen Cruise Lines пропонує свої мистецькі клуби та флагманські програми для гольфу; i Royal Olympia Cruises нещодавно прийняли стратегію «Інтелектуальний спосіб 
побачити світ», щоб відобразити свою прихильність культурному круїзу.

Круїз Celebrity Cruises Celebrity виділив спеціальні конференцзали, встановлені Sony. Він має конференц-зал, який вміщує 242 людини, i оснащений новітніми аудіовізуальними системами, можливістю синхронного мовного перекладу, можливостями для мультимедійних презентацій. Протягом декількох років Star Cruises просуває свою програму «Meetings At Sea» в рамках конференції, стимулів та конференцій, а потім організував найбільшу в своєму роді офшорну конференцію, яку коли-небудь проводили в регіоні Південно-Східної Азії. Туристична галузь впливає як позитивно, так i негативно на економічне, соціокультурне та природне середовище. Круїзна індустрія не $є$ винятком, і для такої невеликої ніші її вплив непропорційний її розмірам. По-перше, це має значний економічний вплив. Наприклад, американська круїзна індустрія створює понад 450 000 робочих місць, що становить 15 мільярдів доларів США заробітної плати та мільярди доларів на придбання товарів та послуг. По-друге, галузь також впливає на доходи та видатки місцевого самоврядування. Доходи, отримані органами місцевого самоврядування від круїзної галузі, можуть бути отримані за рахунок: податків з продажу, що формуються місцевими органами влади в результаті місцевих витрат пасажирів круїзних суден, екіпажу та безпосередньо з круїзних ліній; тимчасові податки на номер, сплачені пасажирами круїзу; доходи від зборів, сплачуваних круїзними лініями та пасажирами круїзу, включаючи збори за док-станцію, збори за сміття та інші портові збори; збори за вивезення сміття та збори за продаж води; пасажирські збори, включаючи вхід і оплату медичних послуг; податкові платежі, що здійснюються підприємствами, що продають товари та послуги для круїзу відвідувачів, або податки 3 продажу, сплачені бізнесом; місцеві закупівлі на підтримку їх господарських операцій; вторинні або непрямі податкові надходження (такі як сплата податку з продажу та майна), що здійснюються працівниками (та їхніми утриманцями) круїзної галузі.

Висновок та перспективи подальших досліджень. Протягом останнього десятиліть круїзна галузь була туристичною нішею, яка пережила найшвидший з усіх темпів зростання. Хоча світовий попит на міжнародні поїздки зріс приблизно на 4,3\%, круїзний ринок виріс на 7,9\%. Однак ця форма туризму ще перебуває в зародковому стані і не була порівняно добре досліджена. Отже, потрібні ретельні дослідження з цього питання, щоб глибше зрозуміти круїзний туризм. Все це у майбутньому стане підґрунтям розвитку круїзної індустрії на більш надійних засадах.

\section{Література:}

1. CLIA (2005c) CLIA Cruise Lines ride the wave of unprecedented growth. Cruise Lines International Association News Release, 16 March. URL: www.cruising.org

2. Davidoff. P. G. and Davidoff. D. S. (1994) Sales and Marketing For Travel \& Tourism. 2nd edn. Prentice- Hall. UK.

3. Dickinson. B. and Vladimir. A. (1997) Selling the Sea: An Inside Look at the Cruise Industry. John Wiley \& Sons. New York.

4. Dowling. R. K. and Vasudavan. T. (2000) Cruising in the new millennium. Tourism Recreation Research 25(3). 17-27. 
5. Knego. P. (2004) Ship of the month: Oosterdam. Cruise Travel 26(1). 30-35.

6. Paige. M. M. (1998) Caribbean cruising towards the millennium. World Travel \& Tourism Development 3. 77-80.

7. Peisley. T. (1989) New developments in world cruising. ElU Travel and Tourism Analyst 7. 5-19.

8. WTO (World Tourism Organization) (2021) Worldwide Cruise Ship Activity. World Tourism Organization. Madrid.

The article considers the peculiarities of the cruise industry development in the world. Today, ships are not seen as a vehicle, but as hotels on the water. Increasingly, they are considered as floating resorts. Cruise companies are increasingly promoting and positioning their brands to enable customers to identify their services as competition grows. This allows customers to make fewer price comparisons and make decisions easier.

Key cruise regions are the Caribbean, Europe and Alaska. This growth is illustrated by the large number of cruise ships, cruise lines and the emergence of cruise corporations. Today, the three main ones are Carnival, Royal Caribbean International and Star Cruise Corporation. a number of key segments have been identified that need attention to meet the projected increase. These include sustainability, safety and product development. Sustainability is a major issue for cruise ships, and the cruise industry has quickly adopted sustainable principles in its development and operations.

Cruise consumers are frequent travelers. Cruisers are looking for new experiences, looking for undiscovered destinations, and feel quite comfortable in other cultures. According to industry experts $[2,5]$, the cruise will be supported by significant consumer demand, new introduction of ships, greater accessibility of American ports and renewed interest in exotic ports.

The main cruise territories are North and Central America $(57 \%$ of the market), Europe (24\%) and the rest of the world (16\%). while $3 \%$ of courts are idle at any given time. The main cruise area is the Caribbean, based on its proximity to the North American market, followed by the Mediterranean, Alaska and the Pacific. The tourism industry has both positive and negative effects on the economic, socio-cultural and natural environment. The cruise industry is no exception, and for such a small niche, its impact is disproportionate to its size. Therefore, careful research on this issue is needed to better understand cruise tourism. All this in the future will be the basis for the development of the cruise industry on a more reliable basis.

Therefore, careful research on this issue is needed to better understand cruise tourism. All this in the future will be the basis for the development of the cruise industry on a more reliable basis. 